\title{
DETERMINAN KEJADIAN DIARE PADA BALITA DI WILAYAH KERJA PUSKESMAS BAKUNG TAHUN 2017
}

\author{
Laras Ayu Wandira ${ }^{1)}$
}

\begin{abstract}
Abstrak
Tempat Pemrosesan Akhir (TPA) Sampah merupakan salah satu tempat yang beresiko sebagai tempat penyebaran penyakit, dikarenakan banyaknya bahan pencemaran seperti lindi, vektor penyakit seperti lalat. Penderita diare di wilayah kerja Puskesmas bakung paling banyak di derita balita yaitu 33,78\% atau 161 kasus dari 477 kasus. Tujuan umum penelitian ini untuk mengetahui determinan kejadian diare pada balita.

Rancangan penelitian yang digunakan adalah case control, penelitian dilakukan pada bulan Mei - Juni 2017 di wilyah kerja Puskesmas Bakung Kota Bandar Lampung. Populasi adalah seluruh balita di wilayah kerja Puskesmas Bakung pada periode bulan Januari sampai Maret 2017, sebanyak 2.813 jiwa. Sampel berjumlah 70 terbagi atas kelompok kasus dan kelompok kontrol yang tidak berpadanan

Hasil penelitian ini $71,4 \%$ jarak rumah responden dengan TPA sudah memenuhi syarat $(>1 \mathrm{~km})$, $65,7 \%$ kepadatan lalat di dalam rumah responden sudah memenuhi syarat, 70,0\% air bersih responden tidak memenuhi syarat, $84,3 \%$ perilaku CTPS Ibu tidak baik. Sedangkan dari ke lima variabel yang diteliti hanya variabel air bersih yang terdapat hubungan dengan kejadian diare, dengan $p$-value 0,001 dengan OR 7,391 (CI 95\%; 2,130-25,151).
\end{abstract}

Kata Kunci : Diare, Penyebaran Penyakit Menular, TPA

${ }^{1)}$ Alumni Prodi D4 Kesehatan Lingkungan Poltekkes Tanjungkarang

\section{PENDAHULUAN}

Penyakit diare masih merupakan masalah global dengan derajat kesakitan dan kematian yang tinggi di berbagai negara terutama di negara berkembang, dan sebagai salah satu penyebab utama tingginya angka kesakitan dan kematian anak di dunia. Secara umum, diperkirakan lebih dari 10 juta anak berusia kurang dari 5 tahun meninggal setiap tahunnya, dan sekitar 20\% meninggal karena infeksi diare (Buletin Diare Kemenkes RI, 2011).

Kondisi memperihatinkan ini juga terjadi di Indonesia dimana lebih dari 400 anak-anak yang meninggal setiap hari di Indonesia akibat penyakit yang mudah dicegah dan diobati seperti pneumonia dan diare. Biasanya, anakanak tersebut adalah anak-anak dari keluarga miskin dan paling terpinggirkan (Unicef, 2013). Bila dilihat per kelompok umur diare tersebar di semua kelompok umur dengan prevalensi tertinggi terdeteksi pada anak balita (1-4 tahun) yaitu 16,7\% (Riskesdas, 2007). Prevalensi diare paling tinggi terjadi pada anak yang tinggal di rumah tanpa akses air bersih, yaitu yang memakai fasilitas kakus di sungai/ kolam/ danau (18,4\%). Pada tahun 2015 di Bandar
Lampung jumlah perkiraan kasus diare sebanyak 20.957 kasus, dengan kasus diare ditangani sebanyak 18.098 kasus (86\%) (Dinkes Kota Bandar Lampung, 2015).

Tahun 2015 di Puskesmas Bakung, diare merupakan salah satu penyakit berbasis lingkungan tertinggi nomor 2 setelah ISPA. Data pada bulan Oktober sampai dengan bulan Desember tahun 2016 angka kejadian diare pada semua umur yaitu 477 kasus, data diatas diketahui jumlah penderita yang paling banyak berasal dari balita yaitu 33,78\% atau 161 kasus dari 477 kasus pada semua umur. Faktor risiko yang sangat berpengaruh untuk terjadinya diare pada balita yaitu status kesehatan lingkungan (penggunaan sarana air bersih, jamban keluarga, pembuangan sampah, pembuangan air limbah) dan perilaku hidup sehat dalam keluarga. Sedangkan secara klinis penyebab diare dapat dikelompokkan dalam enam kelompok besar yaitu infeksi (yang meliputi infeksi bakteri, virus dan parasit), malabsorpsi, alergi, keracunan (keracunan bahan-bahan kimia, keracunan oleh racun yang dikandung dan diproduksi baik jazad renik, ikan, buahbuahan , sayur-sayuran, algae dll), imunisasi, 
defisiensi dan sebab-sebab lain (Sinthamurniwaty, 2006). Cara penyebaran penyakit menular melalui berbagai media dikenal sebagai penyebaran 5F (Food, Fingers, Fluids, Flies, Field/floors) (Soemirat, 2010).

Tempat Pembuangan Akhir (TPA) adalah tempat untuk menimbun sampah dan merupakan bentuk tertua perlakuan sampah. Jenis pengelolaan sampah yang digunakan di TPA Bakung adalah Open dumping, dalam pengelolaan ini sampah dibuang begitu saja dalam sebuah tempat pembuangan akhir tanpa ada perlakuan apapun. Open dumping merupakan jenis pembuangan sampah akhir yang tidak saniter karena pada sampah basah dapat menjadi media yang baik untuk vektor penular penyakit. Menurut Permen PU No. 3 Tahun 2010 tentang Penyelenggaraan Prasarana dan Sarana Persampahan Dalam Penanganan Sampah Rumah Tangga dan Sampah Sejenis Sampah Rumah Tangga dikatakan pada pasal 35 ayat 2 (e) jarak TPA dari permukiman, yaitu lebih dari $1 \mathrm{~km}$ (satu kilometer) dengan mempertimbangkan pencemaran lindi, kebauan, penyebaran vektor penyakit, dan aspek sosial. Namun berdasarkan hasil pengamatan masih ada pemukiman penduduk yang jarak dengan TPA kurang dari $1 \mathrm{~km}$.

\section{METODE}

Penelitian ini merupakan penelitian analitik, yaitu penelitian yang mencoba menggali bagaimana dan mengapa fenomena kesehatan yang terjadi kemudian melakukan analisis dinamika korelasi anatara fenomena atau antara faktor resiko dengan faktor efek (Notoatmodjo, 2010). Rancangan penelitian yang digunakan adalah Case Control, waktu Penelitian dilakukan pada bulan Mei - Juni dengan lokasi penelitian di wilyah kerja Puskesmas Bakung Kota Bandar Lampung Tahun 2017. Populasi dalam penelitian ini adalah seluruh penduduk atau orang di wilayah kerja Puskesmas Bakung Kota Bandar Lampung yang memiliki balita pada periode bulan Januari sampai Maret 2017 yaitu sebanyak 2.813 jiwa. Sampel terbagi atas kelompok kasus dan kelompok kontrol yang tidak berpadanan diambil dengan kriteria :

1) Kasus

Kasus adalah seluruh penduduk atau orang di wilayah kerja Puskesmas Bakung Kota Bandar Lampung yang memiliki balita yang datang ke Puskesmas Bakung dan dinyatakan menderita diare oleh Dokter atau petugas medis puskesmas serta tercatat dalam buku register diare.

2) Kontrol

Kontrol adalah seluruh penduduk atau orang di wilayah kerja Puskesmas Bakung Kota Bandar Lampung yang memiliki balita yang datang ke Puskesmas Bakung dan tidak dinyatakan menderita diare oleh Dokter atau petugas medis puskesmas namun memiliki kriteria (umur, kelurahan, tanggal berobat) yang sama dengan sampel kasus.

Besar sampel sebanyak 70 sampel ditentukan dari nilai Po dan OR menggunakan hasil penelitian terdahulu, dengan perbandingan 1:1 terdiri dari 35 kasus dan 35 kontrol sampel kasus di ambil dengan cara :

1. Daftar semua balita yang menderita diare pada 3 bulan terakhir

2. Pilih dari urutan bawah nama / daftar balita yang menderita diare

3. Lakukan hingga jumlah yang diinginkan dapat dicapai.

Sedangkan dalam pemilihan sample kontrol yang dipilih adalah penduduk atau orang yang memiliki balita yang datang ke Puskesmas Bakung dalam 3 bulan terakhir yaitu bulan maret - mei dan tidak dinyatakan menderita diare oleh Dokter atau petugas medis puskesmas. Data-data yang diperoleh kemudian di analisa secara univariat dan bivariat untuk mengetahui apakah ada hubungan antara faktor-faktor penderita dengan kajadian diare pada balita di wilayah kerja Puskesmas Bakung Kota Bandar Lampung dengan menggunakan uji Chi-square.

\section{HASIL}

\section{Hubungan Jarak Rumah dengan Kejadian Diare}

Berdasarkan pada hasil gambaran mengenai jarak rumah, dapat dijelaskan, pada kelompok penderita diare, terdapat $31,43 \%$ jarak rumah dengan TPA tidak memenuhi syarat dan $68,57 \%$ memenuhi syarat. Pada kelompok tidak diare $25,71 \%$ jarak rumah dengan TPA tidak memenuhi syarat dan $74,29 \%$ memenuhi syarat. Hasil analisis bivariat menyatakan $\mathrm{p}$ value $=$ 0,791 yang berarti bahwa tidak ada hubungan yang bermakna antara jarak rumah dengan TPA dengan kejadian diare. 
Tabel 1. Hubungan Jarak rumah Dengan Kejadian Diare

\begin{tabular}{|c|c|c|c|c|c|c|}
\hline \multirow{2}{*}{ Jarak rumah } & \multicolumn{2}{|c|}{ Diare } & \multicolumn{2}{|c|}{ Tidak diare } & \multirow{2}{*}{$\mathrm{p}$-value } & \multirow{2}{*}{$\begin{array}{c}\text { OR } \\
95 \% \mathrm{CI}\end{array}$} \\
\hline & $\mathrm{n}$ & $\%$ & $\mathrm{n}$ & $\%$ & & \\
\hline TMS & 11 & 31,43 & 9 & 25,71 & \multirow{3}{*}{0.791} & \multirow{3}{*}{$\begin{array}{c}1,324 \\
(0,467-3,750)\end{array}$} \\
\hline MS & 24 & 68,57 & 26 & 74,29 & & \\
\hline Jumlah & 35 & 100,00 & 35 & 100,00 & & \\
\hline
\end{tabular}

\section{Hubungan Kepadatan Lalat dengan Kejadian Diare}

Tabel 2 menggambarkan mengenai kepadatan lalat, pada kelompok penderita diare terdapat 54,29\% jarak rumah dengan TPA tidak memenuhi syarat dan $45,71 \%$ memenuhi syarat. Pada kelompok tidak diare 34,29\% jarak rumah dengan TPA tidak memenuhi syarat dan $65,71 \%$ memenuhi syarat. Hasil analisis bivariat menyatakan $\mathrm{p}$ value $=0,149$ yang berarti bahwa tidak ada hubungan yang bermakna antara kepadatan lalat dengan kejadian diare.

Tabel 2. Hubungan Kepadatan Lalat Dengan Kejadian Diare

\begin{tabular}{|c|c|c|c|c|c|c|}
\hline \multirow{2}{*}{ Kepadatan lalat } & \multicolumn{2}{|c|}{ Diare } & \multicolumn{2}{|c|}{ Tidak diare } & \multirow{2}{*}{$\mathrm{p}$-value } & \multirow{2}{*}{$\begin{array}{c}\mathrm{OR} \\
95 \% \mathrm{CI} \\
\end{array}$} \\
\hline & $\mathrm{n}$ & $\%$ & $\mathrm{n}$ & $\%$ & & \\
\hline TMS & 19 & 54,29 & 12 & 34,29 & \multirow{3}{*}{0.149} & \multirow{3}{*}{$\begin{array}{c}2,276 \\
(0,868-5,969)\end{array}$} \\
\hline MS & 16 & 45,71 & 23 & 65,71 & & \\
\hline Jumlah & 35 & 100,00 & 35 & 100,00 & & \\
\hline
\end{tabular}

\section{Sanitasi makanan}

Hasil penelitian tentang sanitasi makanan (Tabel 3) menunjukan sebanyak 60,0\% sanitasi makanan responden tidak memenuhi syarat. Pada penelitian ini hasil proporsinya menunjukan lebih tinggi pada kelompok responden yang menderita diare dan sanitasi makanannya sudah memenuhi syarat di banding responden bukan penderita diare dan sanitasi makanannya sudah memenuhi syarat, meskipun hasilnya tidak jauh berbeda. Pada kelompok responden yang menderita diare, terdapat $22,86 \%$ sanitasi makanannya idak memenuhi syarat dan 77,14\% memenuhi syarat. Pada kelompok responden yang tidak menderita diare, $31,43 \%$ sanitasi makananya tidak memenuhi syarat dan $68,57 \%$ memenuhi syarat. Hasil uji Chi Square diperoleh p-value lebih besar dari alpha $(0.591>0,05)$ dengan demikian tidak ada hubungan yang bermakna antara sanitasi makanan terhadap kejadian penyakit diare pada penelitian ini.

Tabel 3. Hubungan Sanitasi Makanan Dengan Kejadian Diare

\begin{tabular}{|c|c|c|c|c|c|c|}
\hline \multirow{2}{*}{ Sanitasi Makanan } & \multicolumn{2}{|c|}{ Diare } & \multicolumn{2}{|c|}{ Tidak diare } & \multirow{2}{*}{$\mathrm{p}$-value } & \multirow{2}{*}{$\begin{array}{c}\text { OR } \\
95 \% \mathrm{CI}\end{array}$} \\
\hline & $\mathrm{n}$ & $\%$ & $\mathrm{n}$ & $\%$ & & \\
\hline TMS & 8 & 22,86 & 11 & 31,43 & & \\
\hline MS & 27 & 77,14 & 24 & 68,57 & 0.591 & 0,646 \\
\hline Jumlah & 35 & 100,00 & 35 & 100,00 & & $(0,223-1,873$ \\
\hline
\end{tabular}

\section{Air Bersih}

Air bersih yang terdapat di rumah responden pada penelitian ini sebanyak $70 \%$ tidak memenuhi syarat, pada hasil analisis bivariat proporsi terbanyak berada pada kelompok penderita diare yang airnya tidak memenuhi syarat. Hasil penelitian tentang ada tidaknya hubungan antara air bersih dengan kejadian diare di Wilayah Kerja Puskesmas Bakung tahun 2017 selengkapnya dapat dilihat pada Tabel 4. 
Tabel 4. Hubungan Air Bersih dengan Kejadian Diare

\begin{tabular}{|c|c|c|c|c|c|c|}
\hline \multirow{2}{*}{ Air Bersih } & \multicolumn{2}{|c|}{ Diare } & \multicolumn{2}{|c|}{ Tidak diare } & \multirow{2}{*}{$\mathrm{p}$-value } & \multirow{2}{*}{$\begin{array}{c}\text { OR } \\
95 \% \mathrm{CI} \\
\end{array}$} \\
\hline & $\mathrm{n}$ & $\%$ & $\mathrm{n}$ & $\%$ & & \\
\hline TMS & 31 & 88,57 & 18 & 51,43 & \multirow{3}{*}{0.002} & \multirow{3}{*}{$\begin{array}{c}7,391 \\
(2,130-25,151)\end{array}$} \\
\hline MS & 4 & 11,43 & 17 & 48,57 & & \\
\hline Jumlah & 35 & 100,00 & 35 & 100,00 & & \\
\hline
\end{tabular}

Berdasarkan Tabel 4 diketahui 88,57\% responden yang menderita diare yang air bersihnya tidak memenuhi syarat dan $11,43 \%$ memenuhi syarat. 51,43\% responden yang tidak terkena penyakit diare air bersihnya tidak memenuhi syarat dan $48,57 \%$ memenuhi syarat. Hasil uji Chi Square diperoleh p-value lebih kecil dari alpha $(0.002<0,05)$ dengan terdapat hubungan yang bermakna antara air bersih terhadap kejadian penyakit diare. Dengan adanya hubungan yang bermakna antara air bersih dengan kejadian diare maka terdapat pula resiko sebanyak 7,4 kali lebih besar bagi responden yang air bersihnya tidak memenuhi syarat terkena penyakit diare.

\section{Perilaku CTPS Ibu}

Pada analisis sebelumnya didapatkan gambaran mengenai proporsi perilaku CTPS ibu yang tidak baik sebesar $84,3 \%$. Pada hasil analisis bivariat didapatkan proporsi terbanyak terdapat pada kelompok kejadian diare dengan perilaku CTPS tidak baik. Namun hasil tersebut nilainya tidak jauh berbeda dengan kelompok bukan diare dan perilaku CTPSnya tidak baik. Hasil penelitian tentang ada tidaknya hubungan perilaku CTPS ibu dengan kejadian diare pada penelitian ini selengkapnya dapat terlihat pada tabel 3. Dapat dijelaskan bahwa pada kelompok diare, 97,14\% ibu melakukan CTPS dengan tidak baik dan $8,57 \%$ baik. Sedangkan pada kelompok tidak diare $77,14 \%$ ibu melakukan CTPS dengan tidak baik dan 22,86\% baik. Hasil uji Chi Square diperoleh $p$-value lebih besar dari alpha $(0.189>0,05)$ dengan demikian tidak terdapat hubungan yang bermakna antara perilaku CTPS terhadap kejadian penyakit diare.

Tabel 5. Hubungan Perilaku CTPS Ibu dengan Kejadian Diare

\begin{tabular}{|c|c|c|c|c|c|c|}
\hline \multirow{2}{*}{ CTPS Ibu } & \multicolumn{2}{|c|}{ Diare } & \multicolumn{2}{|c|}{ Tidak diare } & \multirow{2}{*}{$\mathrm{p}$-value } & \multirow{2}{*}{$\begin{array}{c}\mathrm{OR} \\
95 \% \mathrm{CI}\end{array}$} \\
\hline & $\mathrm{n}$ & $\%$ & $\mathrm{n}$ & $\%$ & & \\
\hline TMS & 32 & 91,43 & 27 & 77,14 & \multirow{3}{*}{0.189} & \multirow{3}{*}{$\begin{array}{c}3,160 \\
(0,762-13,106)\end{array}$} \\
\hline MS & 3 & 8,57 & 8 & 22,86 & & \\
\hline Jumlah & 35 & 100,00 & 35 & 100,00 & & \\
\hline
\end{tabular}

\section{PEMBAHASAN}

\section{Jarak Rumah dengan TPA}

Saat observasi ke lapangan masih banyak rumah-rumah warga yang sangat dekat dengan TPA Bakung bahkan ada yang hanya berjarak $\pm 500 \mathrm{~m}$ dengan TPA Bakung. Berdasarkan hasil penelitian rata - rata jarak rumah responden adalah $2893 \mathrm{~m}$ atau $2,89 \mathrm{~km}$, dengan jarak terdekat yaitu $599 \mathrm{~m}$ dan jarak terjauh adalah $6700 \mathrm{~m}$ atau 6,7 km. Menurut Kepmen PU Pera (2010), Jarak rumah dengan TPA yaitu lebih dari $1 \mathrm{~km}$ (satu kilometer) dengan mempertimbangkan pencemaran lindi, kebauan, penyebaran vektor penyakit, dan aspek sosial. Selain itu menurut penelitian Yuliana (2001) menyebutkan bahwa penyakit diare dan kudis adalah penyakit yang paling banyak dikeluhkan oleh warga disekitar TPA.
Dekatnya pemukiman dengan TPA yang merupakan tempat yang cocok bagi organisme dan menarik bagi berbagai binatang seperti lalat, tikus, kecoa dan nyamuk yang tentu dapat menimbulkan penyakit. Sampah organik dan sampah anorganik (kaleng, botol, plastik) merupakan sarang patogen dan vektor penyakit. Berbagai penyakit yang dapat muncul karena sampah yang tidak dikelola antara lain adalah, diare, disentri, cacingan, malaria, kaki gajah (elephantiasis) dan demam berdarah. Menurut Depkes RI (1992) jarak terbang efektif lalat adalah 450-900 $\mathrm{m}$, hal tersebut pula yang menjadi salah satu alasan jarak rumah dengan TPA harus $>1 \mathrm{~km}$.

Selain vektor penyakit menurut penelitian Yuliana (2017) TPA berpengaruh terhadap cemaran sumber air bersih akibat rembesan air 
lindi, terutama sumur yang berjarak sekitar 100 $\mathrm{m}$ dengan lokasi TPA. Turunnya hujan akan mengakibatkan peningkatan limpasan air di wilayah TPA, sekaligus membawa bahan-bahan organik dan anorganik yang telah terurai dan tersuspensi, yang terbawa bersama lindi meresap ke lapisan tanah dan masuk ke air sumur galian di sekitar lokasi TPA.

Menurut penelitian Irhamni (2017) kandungan logam berat pada air lindi menunjukkan bahwa konsentrasi logam berat besi $(\mathrm{Fe})$ merupakan logam tertinggi yang ditemukan pada air limbah lindi TPA Kota Banda Aceh yang mencapai 10,9191 ppm. Logam berat lainnya yang tergolong essensial (logam dalam jumlah tertentu yang sangat dibutuhkan oleh organisme) seperti $\mathrm{Zn}, \mathrm{Cu}, \mathrm{Fe}$, Co, dan Mn ditemukan dengan konsentrasi yang kecil. Selanjutnya, logam berat $\mathrm{Hg}, \mathrm{Cd}$, $\mathrm{Pb}$, dan $\mathrm{Cr}$ yang termasuk logam berat nonesensial (keberadaannya dalam tubuh masih belum diketahui manfaatnya) contohnya yaitu: $\mathrm{Hg}, \mathrm{Cd}, \mathrm{Pb}, \mathrm{Cr}$, dan lainnya. Logam berat yang juga ditemukan, dan hanya logam $\mathrm{Hg}$ pada golongan ini yang ditemukan di atas standar SNI dengan konsentrasi 0,00463 ppm.

Logam merkuri bersifat toksik sehingga berbahaya apabila masuk ke dalam tubuh manusia. Keracunan merkuri dapat mengakibatkan kerusakan pada sistem saraf, pencernaan, dan ginjal. Pada wanita hamil, merkuri dapat melewati plasenta dan mencapai janin, dimana janin lebih mudah terkena efek samping merkuri dari pada orang dewasa. Sayangnya, merkuri yang masuk dalam tubuh manusia tidak mudah keluar dengan sendirinya. Akumulasi ini dalam jangka waktu yang lama, dapat menyebabkan gangguan dan kerusakan bagi organ-organ tersebut (Suhendrayatna 2013, dalam Irhamni 2017). Sumber utama timbal adalah berasal dari komponen gugus alkyl timbal yang digunakan sebagai bahan additive bensin, dan juga makanan dan minuman. Komponen ini beracun terhadap seluruh aspek kehidupan dan menunjukkan beracun pada sistem saraf, hematologi, hematotoxid dan mempengaruhi kerja ginjal (Suhendrayatna 2007 dalam Irhamni 2017).

Keberadaan logam besi, cadmium, dan kromium dalam air lindi TPA sangat berbahaya karena logam ini adalah logam yang bersifat sangat toksik. Logam besi, cadmium, dan krom yang berada dalam lindi akan merembes ke dalam tanah yang akan mencemari air tanah. Jika ketiga logam ini merembes ke dalam tanah maka akan mencemari sumur-sumur penduduk (Nonong 2010 dalam Irhamni 2017). Linsley dan Franzini (1985) menyatakan bahwa bakteri tanah akan hilang setelah meresap sejauh $30 \mathrm{~m}$ pada tanah bertekstur halus. Bakteri patogen yang biasanya disebarkan melalui air adalah bakteri disentri, kolera dan tipus.

Meskipun pada penelitian ini tidak terdapat hubungan antara jarak rumah dengan TPA terhadap kejadian diare namun warga/ responden yang bermukim $\leq 1 \mathrm{~km}$ dengan TPA Bakung tetap disarankan mengenai beberapa hal yang meliputi penanggulangan vektor penyebab penyakit (lalat, tikus, dan kecoa) dan cemaran air tanah akibat air lindi yang mungkin sudah mencemari air tanah baik dari segi kimia maupun bakteriologi.

Untuk menghindari banyaknya vektor penyebab penyakit (lalat, nyamuk, kecoa, tikus dll) yang ada dapat melakukan penanggulan baik dari segi teknis (pemasangan kawat kasa, menjaga kebersihan rumah, dll) maupun dengan bahan kimia (pestisida dengan sesuai takaran). Dan untuk menaggulangi cemaran lindi pada air tanah dari segi bakteriologi adalah dengan memasak terlebih dahulu air tersebut jika air tersebut digunakan sebagai air minum atau sebaiknya menggunakan air minum kemasan (galon) dan untuk menghindari terdapatnya cemaran kimia maka sebaiknya menggunakan air bersih dari sumber lain atau membeli.

\section{Kepadatan Lalat}

Lalat dianggap mengganggu karena kesukaannya hinggap di tempat-tempat yang lembab dan kotor, seperti sampah. Lalat yang paling banyak terdapat di rumah adalah jenis Musca domestica.Pada penelitian ini peneliti mengukur kepadatan lalat dengan menggunakan alat Fly Grill, Fly Grill diletakan di satu titik di rumah responden kemudian lalat yang hinggap di Fly Grill dihitung dengan menggunakan counter, penghitungan dilakukan per 30 detik sebanyak 10 kali, durasi sekali penghitungan yaitu 30 detik. Pada hasil perhitungan tersebut proporsi kepadatan lalat yang tidak memenuhi syarat hanya $34,3 \%$ saja dan responden yang kepadatan lalatnya tidak memenuhi syarat sebagian besar berjarak dekat dengan TPA Bakung. Hasil uji statistik dengan menggunakan Chi Square diperoleh p-value lebih besar dibandingkan dengan nilai alpha $(0,149>0,05)$ dengan demikian tidak ada hubungan antara kepadatan lalat terhadap kejadian penyakit diare di Wilayah Kerja 
Puskesmas Bakung pada penelitian ini. Tidak adanya hubungan antara kepadatan lalat dengan kejadian diare dapat disebabkan karena proporsi penderita diare yang kepadatan lalatnya tidak memenuhi syarat di banding dengan bukan penderita diare dan kepadatan lalatnya juga tidak memenuhi syarat tidak jauh berbeda, dengan demikian hal tersebut menjadi salah satu hal yang menyebabkan tidak terdapatnya hubungan antara kepadatan lalat dengan kejadian diare di Wilayah kerja Puskesmas Bakung.

Hasil penelitian Wijayanti (2009) dengan penelitiannya mengenai hubungan kepadatan lalat dengan kejadian diare pada anak balita di Marelan dan membuktikan secara ilmiah dengan menggunakan uji chi-square bahwa kepadatan lalat memiliki hubungan signifikan dengan kejadian diare. Semakin padat kepadatan lalat, semakin besar peluang terjadinya diare pada anak balita. Jika makanan yang dihinggapi lalat akan tercemar oleh mikroorganisme baik bakteri, protozoa, telur/larva cacing atau bahkan virus yang dibawa dan dikeluarkan dari mulut lalat -lalat dan bila dimakan oleh manusia, maka dapat menyebabkan penyakit diare (Andriani, 2010).

Lalat merupakan salah satu vektor yang harus dikendalikan karena dapat pengganggu aktifitas dan kesehatan masyarakat. Sebagai alat transportasi yang sangat baik dalam penularan penyakit, lalat sangat menyukai tempat yang tidak berangin, tetapi sejuk dan kalau malam hari sering hinggap di semak-semak di luar tempat tinggal, lebih menyukai makanan yang bersuhu tinggi dari suhu udara sekitar dan sangat membutuhkan air (Widyati \& Yuliarsih, 2002).

Meskipun dalam penelitian ini menujukkan tidak terdapat hubungan antara kepadatan lalat dengan kejadian diare pada balita, namun warga/responden yang kepadatan lalat di rumahnnya tinggi dan berdekatan dengan TPA disarankan untuk mengurangi atau menghilangkan tempat perindukan lalat, hal yang dapat dilakukan adalah upaya perbaikan hygiene dan sanitasi lingkungan rumah atau meningkatkan kesadaran masyarakat terhadap kebutuhan akan lingkungan yang bersih, penataan hunian rumah yang sehat. Melindungi makanan, peralatan makan agar tidak dihinggapi lalat dengan cara memasukan makanan ke dalam lemari atau menutup rapat makanan. Jendela dan ventilasi rumah dipasang kawat kasa, pintu masuk dilengkapi dengan gorden, memasang stik perekat anti lalat jika diperlukan untuk mencegah atau mengurangi lalat masuk ke dalam rumah dan mengurangi bahaya terhadap kontaminasi makanan oleh lalat. Bisa juga dengan usaha pengendalian dengan menggunakan insektisida sesuai aturan pemakaian.

\section{Sanitasi Makanan}

Sanitasi makanan adalah salah satu usaha pencegahan yang menitik beratkan kegiatan dan tindakan yang perlu untuk membebaskan makanan dan minuman dari segala bahaya yang dapat menganggu atau merusak kesehatan, mulai dari sebelum makanan di konsumsi, selama dalam proses pengolahan, penyimpanan, pengangkutan, sampai pada saat dimana makanan dan minuman tersebut siap untuk dikonsumsikan kepada konsumen. Sanitasi makanan ini bertujuan untuk menjamin keamanan dan kemurnian makanan, mencegah konsumen dari penyakit. Sanitasi makanan yang di maksud dalam penelitian ini adalah kualitas mikrobiologi yang ada pada alat makan balita (mangkuk) dan angka kuman makanan yang dimakan oleh balita.

Pemeriksaan angka kuman pada makanan dan alat makan balita di lakukan di Laboratorium Jurusan Kesehatan Lingkungan, dalam satu hari peneliti mengambil sabanyak 15 sampel makanan dan 15 sampel usap alat makan balita. Pada saat penelitian angka kuman pada makanan sample yang banyak di ambil adalah nasi, dikarenakan banyaknya responden yang belum memasak lauk pauk yang matang dikarenakan pada saat penelitian bertepatan dengan bulan puasa dan pengambilan sampel dilakukan pada pagi hari. Pada penelitian angka kuman pada alat makan peneliti melakukan pengambilan sample dengan cara aseptik untuk menghindari kontaminasi dari luar, pada saat pengusapan dilakukan sedekat mungkin dengan lampu bunsen dan hasil usapan dimasukkan kedalam box yang berisi es batu. Pada proses pemeriksaan metode yang digunakan adalah ALT (Angka Lempeng Total) dan media yang digunakan adalah PCA (Plate Count Agar).

Menurut penelitian Febriana Widjiastuti 2012 terbukti bahwa pengolahan makanan berhubungan dengan diare dengan nilai $\mathrm{p}=$ 0,016. Terdapat enam perinsip higiene dan sanitasi makanan yaitu pemilihan bahan makanan, penyimpanan bahan makanan, pengolahan bahan makanan, pengangkutan makanan, penyimpanan makanan matang dan 
penyajian makanan (Menteri Kesehatan Republik Indonesia, 2003). Namun pada penelitian ini lebih menitik beratkan terhadap kualitas makanan (mikrobiologi makanan dan alat makan) dikarenakan jika kualitas mikrobiologi tidak memenuhi syarat sudah pasti ke enam perinsip sanitasi makanan tidak baik.

Makanan yang kotor akan berbahaya bagi anggota keluarga karena dapat menyebabkan kejadian diare. Karena itu agar keamanan makanan terjaga, usahakan agar menyimpan makanan pada tempat lemari makan atau meja yang ditutup dengan tutupan saji. Berdasarkan keputusan menteri kesehatan RI Nomor 1096/2011 bahwa alat makan (piring, sendok, ge las, garpu dan gelas) tidak boleh mengandung bakteri lebih dari $100 \mathrm{koloni} / \mathrm{cm}^{2}$, berdasarkan hasil penelitian terhadap 70 responden terdapat $30,0 \%$ responden yang angka kuman pada alat makannya tidak memenuhi persyaratan yang ada dan 70,0\% responden angka kuman pada alat makannya sudah memenuhi syarat. Sedangkan untuk angka kuman pada makanan standar yang digunakan adalah SK DIRJEN (BPOM) No. HK.00.06.1.52.4011 yang menetapkan batas maksimum angka kuman pada makanan adalah $1 \times 10^{4} \mathrm{koloni} / \mathrm{gram}$. Pada pemeriksaan sample makanan balita sebanyak $67,1 \%$ sudah memenuhi persyaratan yang ada dan sebanyak $32,9 \%$ belum memenuhi syarat.

\section{Air Bersih}

Kebutuhan manusia akan air sangat kompleks antara lain untuk minum, masak, mandi, mencuci (bermacam-macam cucian) dan sebagainya. Pada penelitian ini pemeriksaan yang dilakukan adalah pemeriksaan mikrobiologi (coli form) pada air bersih, pemeriksaan dilakukan di Laboratorium Terpadu Poltekkes Tanjung Karang dengan metode MPN (Most Probable Number) dengan 3 tahap pengujian yaitu uji pendugaan, uji penegasan, dan uji pelengkap. Berdasarkan Peraturan Menteri Kesehatan Republik Indonesia Nomor 416 tahun 1990 total Coliform yang diperbolehkan adalah 50MPN/100ml. Selain pemeriksaan kualitas mikrobiologi pada air peneliti juga melakukan observasi terhadap konstruksi sumber air bersih.

Hasil pemeriksaan mendapatkan sebanyak $70 \%$ air bersih responden tidak memenuhi syarat yang ada. Bila dilihat berdasarkan variabel pemeriksaan didapatkan 68,6\% responden kualitas air bersihnya tidak memnuhi syarat secara mikrobiologi (Coliform) dan dari segi konstruksi sebanyak $57,1 \%$ responden yang menggunakan SPT konstruksinya tidak memenuhi syarat, dan sebanyak $38,1 \%$ responden yang menggunakan SGL dari segi konstruksinyapun tidak memenuhi syarat. Hasil uji statistik dengan menggunakan Chi Square di peroleh $p$-value lebih kecil dibandingkan dengan nilai alpha $(0,002<0,05)$ dengan demikian ada hubungan yang bermakna antara air bersih ( kualitas mikrobiologi dan konstruksi SAB) terhadap kejadian penyakit diare di Wilayah Kerja Puskesmas Bakung, dengan demikian maka terdapat resiko sebesar 7,4 kali bagi responden yang air bersihnya tidak baik untuk terkena diare.

Hasil penelitian ini juga sejalan dengan Mahmud yaitu diperoleh hasil uji statistik yaitu $p$-value $=0,022(p \leq 0,05)$ maka dapat disimpulkan ada hubungan antara sarana air bersih dengan kejadian diare. Menurut penelitian yang dilakukan Dian Septika Sari yaitu diperoleh hasil uji statistik yaitu $p$-value $=$ $0,003(p \leq 0,05)$ maka dapat disimpulkan ada hubungan antara kondisi sarana air bersih dengan kejadian diare. Menurut penelitian Yuliana (2001) TPA berpengaruh terhadap cemaran sumber air bersih akibat rembesan air lindi, terutama sumur yang berjarak sekitar 100 $m$ dengan lokasi TPA. Namun pada penelitian ini jarak rumah terdekat hanyalah $\pm 500 \mathrm{~m}$ sehingganya adanya cemaran mikrobiologi pada air banyak dipengaruhi dikarenakan faktor konstruksi yang tidak memenuhi syarat bukan dikarenakan cemaran lindi dari TPA Bakung.

Mikroorganisme dapat berperan sebagai indikator untuk mengetahui kualitas perairan (air permukaan maupun air tanah), terutama virus dan bakteri. Virus dapat berimigrasi sejauh 7 - $38 \mathrm{~m}$ ke arah vertikal dan horizontal dari sumbernya dan dapat bertahan selama 28 hari di dalam tanah. Virus dapat juga bergerak secara vertikal dalam tanah berwarna hitam (kaya bahan organik) sampai pada tanah lempung berpasir. Keadaan ini sangat memacu masuknya virus sampaike lapisan air tanah kedalaman $30 \mathrm{~m}$.

Dikarenakan pada penelitian ini sebanyak 68,6\% Coliform pada air bersih responden tidak memenuhi syarat maka saran yang dapat diberikan kepada warga/responden adalah jika air bersih digunakan sebagai air minum sebaiknya air tersebut dimasak terlebih dahulu hingga mendidih, apabila memungkinkan 
sebaiknya untuk air keperluan minum sebaiknya menggunakan air minum kemasan (galon), pada saat mencuci piring sebaiknya dengan air mengalir.

\section{Perilaku CTPS Ibu}

Salah satu penerapan PHBS dalam tatanan rumah tangga yang dapat mencegah terjadinya diare adalah perilaku cuci tangan pakai sabun (CTPS). Pentingnya CTPS telah dipahami dapat menurunkan kejadian diare hingga 47\%. Hal ini penting diketahui oleh masyarakat agar dapat meningkatkan kesadaran untuk membiasakan CTPS dalam kehidupan sehari-hari (Kemenkes RI, 2011).

Hasil penelitian ini melaporkan tidak ada hubungan antara perilaku CTPS ibu terhadap kejadian penyakit diare di Wilayah Kerja Puskesmas Bakung pada penelitian ini. Dikarenakan tidak terdapat hubungan maka tidak terdapat pula risiko penyakit diare akibat CTPS yang tidak baik dalam penelitian ini. Hasil penelitian ini bertentangan dengan penelitian Silvana (2009) dan Apriyanti (2009) menyatakan bahwa adanya hubungan antara kebiasaan mencuci tangan dengan kejadian diare pada anak.

Diare merupakan salah satu penyakit yang penularannya berkaitan dengan perilaku hidup sehat. Pada penularan seperti ini, tangan sangat memegang peran penting, karena lewat tangan yang tidak bersih makanan atau minuman tercemar kuman penyakit masuk ke tubuh manusia. Tujuan cuci tangan pakai sabun adalah menghilangkan kotoran dan debu yang melekat dipermukaan kulit serta mengurangi jumlah mikroorganisme sementara. Perilaku cuci tangan pakai sabun dengan cara yang benar dan pada waktu yang tepat sangatlah berperan dalam pengendalian kejadian diare pada balita. Meskipun pada penelitian ini tidak terdapat hubungan antara perilaku CTPS ibu dengan kejadian diare namun tetap disarankan pada ibu balita agar lebih aktif dalam kegiatan peningkatan pengetahuan seperti datang ke posyandu dan penyuluhan kesehatan, serta menjadikan perilaku cuci tangan pakai sabun sebagai kebiasaan hidup sehari-hari.

\section{KESIMPULAN}

Penelitian menyimpulkan tidak ada hubungan yang bermakna antara jarak rumah dengan TPA, kepadatan lalat, sanitasi makann dan CTPS ibu dengan kejadian diare. Hanya variabel air bersih yang memiliki hubungan bermakna dengan kejadian dengan p-value sebesar 0.001 dengan OR 7,391 (CI 95\% ;2,130-25,151).

Responden yang memiliki jarak rumah dengan TPA $>1 \mathrm{~km}$ menggunakan air bersih yang dimasak hingga mendidih terlebih dahulu untuk keperluan minum, dikarenakan masih banyaknya kualitas mikrobiologi air yang tidak memenuhi syarat akibat tidak baiknya konstruksi SAB. Bagi peneliti selanjutnya yang akan melakukan penelitian selanjutnya sebaiknya melakukan pemeriksaan kualitas air bersih dari segi kimia untuk mengetahui ada atau tidaknya cemaran kimia akibat air lindi yang berasal dari TPA Bakung. Pada penelitian ini terdapat keterbatasan penelitian pada variabel CTPS ibu dikarenakan tidak melakukan konfirmasi kepada pihak ketiga sebagai konfirmasi kebenaran atas jawaban yang diberikan sehingganya pada peneliti selanjutnya yang akan meneruskan penelitian ini sebaiknya melakukan konfirmasi kepada pihak ketiga terkait perilaku CTPS ibu.

\section{DAFTAR PUSTAKA}

Andriani. 2010. Analisis Faktor Resiko Kejadian Diare Pada Anak Usia Dibawah 2 Tahun di RSUD Koja Jakarta. Jakarta. Universitas Indonesia

Dinas Kesehatan Kota Bandar Lampung Provinsi Lampung, 2016. Profil Kesehatan Provinsi Lampung tahun 2015, Bandar Lampung.

Irhamni., Pandia, S., Purba, E. dan Hasan, W. 2017. Serapan Logam Berat Esensial dan Non Esensial pada Air Lindi TPA Kota Banda Aceh dalam Mewujudkan Pembangunan Berkelanjutan. Jurnal Serambi Engineering 2(3): 134-140

Kemenkes RI, 2011. Jendela Data dan Informasi Kesehatan Situasi Diare di Indonesia, Jakarta. Bulettin Diare, Kemenkes RI, Jakarta.

Sinthamurniwaty, 2006. Faktor-faktor Resiko Kejadian Diare Akut pada Balita, Tesis, Magister Epidemiologi Universitad Diponegoro, Semarang.

Soemirat, Juli, 2010. Epidemiologi Lingkungan Edisi Kedua, Gadjah Mada University Press, Yogyakarta.

SK DIRJEN (BPOM) No. HK.00.06.1.52.4011 yang menetapkan batas maksimum angka kuman pada makanan 
Unicef, 2013. Anak-Anak Adalah Urusan Kita Bersama: Modul 2.0 Panduan untuk menggabungkan hak-hak anak menjadi sebuah kebijakan, kajian dampak, dan laporan berkelanjutan. https://www.unicef. org/indonesia/id/media/4431/file.

Wijayanti, Winda, 2010. Hubungan Antara Pemberian ASI Ekslusif dengan Angka Kejadin Diare pada Bayi Umur 0-6 Bulan di Puskesmas Gilingan Kecamatan Banjarsari Surakarta, Skripsi, Fakultas Kedokteran Universitas Sebelas Maret, Surakarta.
Yuliana, Fitriza, dan Septu Haswindy. 2017. Partisipasi Masyarakat dalam Pengelolaan Sampah Pemukiman pada Kecamatan Tungkil Ilir Kabupaten Tanjung Jabung Barat. Vol.15, Issue 2: 96-111. Kota Jambi: Jurnal Ilmu Lingkungan ISSN 1829

Widyati, R dan Yuliarsih. 2002. Higiene dan Sanitasi Umum dan Perhotelan. Jakarta: PT Gramedia Widiarsana Indonesia. 